Пономарев А.И.,

Уфимский государственный нефтяной технический университет, г. Уфра, Россия;

Рагимов T.T., Шигидин О.A.

ООО «Газпром добыча Уренгой», г. Новый Уренгой, Россия

г. Дубна, Россия

\title{
ОПЫТ ЭКСПЛУАТАЦИИ ГАЗОВОЙ СКВАЖИНЫ С КОНЦЕНТРИЧЕСКИМИ ЛИФТОВЫМИ КОЛОННАМИ
}

Введение: сеноманская газовая залежь Уренгойского нестегазоконденсатного месторождения (УНГКМ) находится на поздней стадии разработки. Снижение пластового давления и дебитов эксплуатационных скважин с лифртовыми колоннами большого диаметра (168 мм) является причиной их остановок из-за накопления жидкости на забое для продувок на факел.

Материалы и методы

исследований: одним из возможных технических решений обеспечения устойчивой работы обводняющихся скважин является применение концентрических лифтовых колонн (КЛК), которое реализовано на одной из сеноманских скважин УНКГМ. При этом для управления продуктивными характеристиками скважины использована интеллектуальная система управления потоками скважинной продукции по центральному и кольцевому каналам лифтта в условиях обводнения конденсационными водами.

Результаты исследований

и их обсуждение: спуск в скважину дополнительной лифтовой колонны малого диаметра (73 мм) при низком пластовом давлении осуществлен без глушения и позволил сохранить продуктивность пласта.

Выводы: $\quad$ анализ параметров использования КЛК и принятых проектных решений позволил выявить и определить перспективы поддержания высокой эффективности использования данного решения.

Ключевые слова: «самозадавливание» скважины, пластовое давление, малодебитная газовая скважина, конденсационная вода, концентрическая лифтовая колонна, центральная листовая колонна, межкольцевое пространство, минимально-необходимая скорость, минимально-необходимый дебит, технологич еский комплекс контроля и управления, режим эксплуатации скважины. 
Ponomarev A.I. ${ }^{*}$, Ragimov T.T.**, Shigidin O.A.**

*Ufa State Petroleum Technological University, Ufa, Russia

** "Gazprom dobycha Urengoy", Novy Urengoy,Russia

\section{EXPERIENCE OF A GAS WELL WITH CONCENTRIC LIFT COLUMNS}

Introduction: the Cenomanian deposit of the Urengoy oil, gas and condensate field (UOGCF) is at the advanced stage of its development. The decrease of terrastatic pressure and the rates of operational wells with production tubes of large diameter $(168 \mathrm{~mm})$ is the reason of its stops due to the acMaterials and research cumulation of liquid at the bottom for expulsion to the torch. methods:

Research results and discussion:

Conclusion:

Keywords:

one of the possible technical solutions to provide operational stability of watering out wells is the application of concentric tubing (CT) which is implemented on one of the wells at the UOGCF. In these circumstances, an intelligence system for controlling the flow of borehole products along the central and annular production tubes channels was used to control the productive characteristics of the well in conditions of flooding with condensation water.

The descent into the well of an additional small-diameter production tube $(73 \mathrm{~mm})$ at low terrastatic pressure was carried out without well kill and allowed to maintain the productivity of the reservoir.

The analysis of the parameters of the concentric tubing usage and the adopted design solutions made it possible to identify and determine the prospects for maintaining the high efficiency of such usage.

«self-killing» of a well, reservoir pressure, low-yield gas well, condensation water, concentric tubing, central tubing, inter-annular space, minimum required speed, minimum required flow rate, process control and management system, well operation mode.

\section{ВВЕДЕНИЕ}

Сеноманская газовая залежь уникального по запасам углеводородов Уренгойского нефтегазоконденсатного месторождения (УНГКМ) залегает на глубине 1030-1280 м [1] и разрабатывается с 1978 года. Начальное пластовое давление в залеже - $12,0 \div 12,5 \mathrm{MПа,} \mathrm{состав} \mathrm{пластового} \mathrm{газа} \mathrm{-}$ метановый.

При обустройстве УНГКМ газовые скважины оснащались эксплуатационными колоннами диаметром $215 \div 245$ мм и насосно-компрессорными трубами (НКТ) диаметром $114 \div 168$ мм, что обеспечивало высокие уровни добычи с отбором газа до 1 млн. м³/сут. Применено кустовое расположение эксплуатационных скважин с общей системой сбора продукции в один газосборный коллектор (ГСК). 
В настоящее время сеноманская залежь УНГКМ находятся на поздней стадии разработки. На Уренгойской площади пластовые давления снизились в 6 раз по сравнению с начальными значениями. Многолетняя эксплуатация скважин на истощение пластовой энергии неизбежно привела к падению их продуктивности. Анализ работы действующего фонда показывает, что основными причинами внеплановых остановок ряда эксплуатационных скважин являются, прежде всего, снижение дебита газа и подъём газо-водяного контакта. Часть газовых скважин, оборудованных НКТ диаметром 168 мм, периодически самопроизвольно останавливаются по причине накопления жидкости (конденсационной воды) на забое, т.к. скорость восходящего потока газа не обеспечивает устойчивый вынос жидкой фазы из лифтовой колонны. Возникновение динамического уровня жидкости в стволе скважины провоцирует начало процесса «самозадавливания», который сопровождается постепенным снижением депрессии на пласт и снижением дебита газа вплоть до полной остановки добывающей скважины. Кроме того, конденсационная вода негативно влияет на состояние коллектора призабойной зоны. Увлажнение гидрофильных слабосцементированных песчаников сеноманской залежи приводит к растворению цементирующего материала и разрушению призабойной зоны пласта, выносу песка в скважину и образованию песчаньх пробок на забое скважины [2]. Кустовое расположение скважин, работающих с различными расходными и термобарическими параметрами в один газосборный коллектор, затрудняет установку оптимального режима эксплуатации для каждой скважины куста. В результате дебиты газа одних скважин куста оказываются ниже потенциально возможных, а другие скважины периодически останавливаются по причине накопления столба жидкости из-за уменьшения скоростей потока газа ниже минимальных значений, обеспечивающих полный и непрерывный вынос жидкости с забоя. Такое явление самопроизвольной остановки скважин получило название «самозадавливание». Восстановление работоспособности скважин требует проведения специальных технологических операций. Традиционным способом восстановления рабочих параметров является кратковременная (от 15 до 60 мин.) отработка скважины на горизонтальную факельную установку (ГФУ). Но эта технологическая операция дает лишь временный эффект, требует периодического повторения (по ряду скважин от 30 до 100 раз в год) и сопровождается «отжигом» скважины на факел, т.е. неизбежно приводит к росту потерь добываемого газа и увеличению техногенной нагрузки на окружающую среду.

Выполнение плановых показателей добычи газа напрямую зависит от стабильной эксплуатации скважин действующего фонда в соответствии с заданным им технологическим режимом. Поэтому в ООО «Газпром добыча Уренгой» постоянно ведется работа по разработке и внедрению технологий добычи газа, направленных на поддержание и повышение работоспособности фонда скважин, в том числе и малодебитных газовых скважин, работаю- 
щих в условиях обводнения конденсационными водами. На различных этапах эксплуатации месторождения был получен опыт применения следующих технологий - замена НКТ на меньший диаметр, подача в скважину твердых и жидких поверхностно-активных веществ (ПАВ), плунжерный лифт. Однако перечисленные технологии имеют существенные ограничения: ПАВ не эффективен в скважинах с подвеской НКТ выше перфорированного интервала; замена НКТ на меньший диаметр уменьшает продуктивность скважины, так как сопровождается глушением и приводит к увеличению гидравлических сопротивлений; плунжерный лифт не получил распространения ввиду низкой конструктивной надежности. В данных обстоятельствах наиболее перспективным является применение технологии эксплуатации обводняющихся малодебитных газовых скважин по конщентрической лифтовой колонне. Использование этой технологии получило распространение в мировой практике и испытано на двух скважинах Медвежьего и Ямбургского НГКМ [3].

\section{Материалы и методы исследований}

В ООО «Газпром добыча Уренгой» технология КЛК получила дальнейшее развитие. Особенностью реализации данной технологии на скважине №514 Уренгойского месторождения был спуск центральной лифтовой колонны (ЦЛК) без глушения, что исключило снижение продуктивности скважины.

В ноябре 2013 г. ранее периодически простаивающая газовая эксплуатационная скважина № 514 куста 51 УКПГ-5 была оборудована КЛК и комплексом телемеханики кустов газовых скважин. 16 декабря 2013 г. скважина № 514 введена в опытно-промышленную эксплуатацию. В качестве ЦЛК была впервые применена отечественная сталеполимерная армированная труба ТГ19/73-10/10-75.

Конструкция скважины №514:

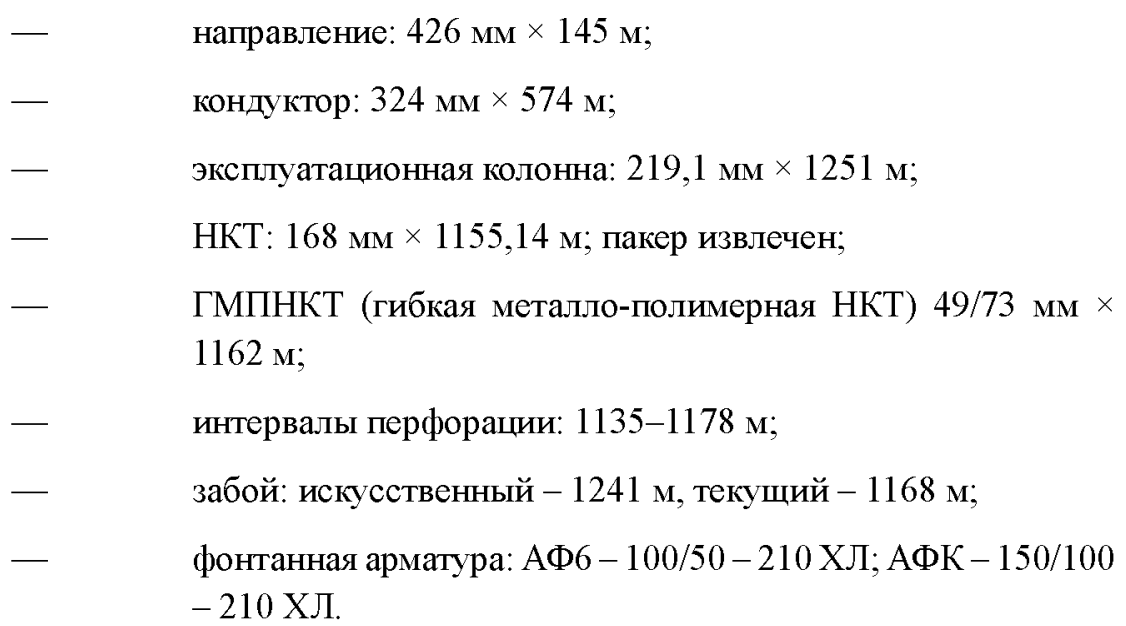


Для обеспечения устойчивого выноса воды из лифтовой колонны скорость восходяшего потока газа должна на 5-10\% превышать значение минимально-необходимой скорости [5, 6]. Расчет минимальной скорости газа, необходимой для выноса жидкости, выполнен по методике ООО «Газпром ВНИИГАЗ».

$$
V_{\min }=3,3\left(\frac{g \cdot \sigma \cdot \rho_{1}^{2} \cdot \sin \alpha}{\rho_{2}^{2} \cdot\left(\rho_{1}-\rho_{2}\right)}\right)^{0,25}
$$

$g-\quad$ ускорение свободного падения, $9,81 \mathrm{~m} / \mathrm{c}^{2}$;

$\sigma-\quad$ коэффициент поверхностного натяжения жидкости, $0,072 \mathrm{H} / \mathrm{M}$;

$\rho_{1}-\quad$ плотность жидкости, $1000 \mathrm{\kappa г} / \mathrm{M}^{3}$;

$\alpha-\quad$ угол наклона ЛК к горизонту, $90^{\circ}$;

$\rho_{2}-\quad$ плотность газа на забое, 14 кг $/ \mathrm{M}^{3}$.

Минимально-необходимая для выноса жидкости расчетная скорость газа в скважине № 514 составила 4,6 м/с.

Результаты расчета скоростей восходящего потока на режимах ГДИ скважины № 514, оборудованной КЛК, и оценочные расчеты скоростей при работе скважины по НКТ 168 мм или НКТ 114 мм приведены на графике рисунка 1 .

Из приведенных на рисунке 1 данных следует:

замена в скважине № 514 НКТ 168 мм на НКТ 114 мм даже при применении технологии без глушения скважины приведет к снижению продуктивности на 30-40 тыс. м²/сут.;

- $\quad$ без оборудования КЛК устойчивая работа скважины №514 в ГСК невозможна, т.к. при работе по НКТ 168 мм или 114 мм продуктивность скважины не обеспечивает устойчивый вынос жидкости из ствола скважины;

при эксплуатации скважины по ЦЛК значения скоростей восходящего потока больше критического значения практически во всем диапазоне изменения дебита газа (до 12 тыс. $\mathrm{M}^{3} /$ сут.), что в дальнейшем было подтверждено экспериментально в процессе мониторинга параметров работы скважины на различных режимах эксплуатации.

Технология эксплуатации скважин по КЛК - процесс добычи газа, в котором газ, поступающий из продуктивного пласта, на забое разделяется на два потока. Потоки газа поднимаются к устью скважины по кана- 


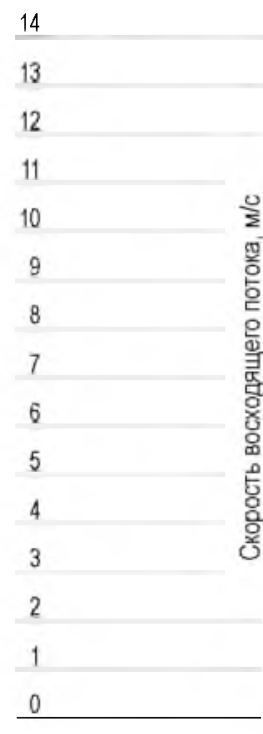
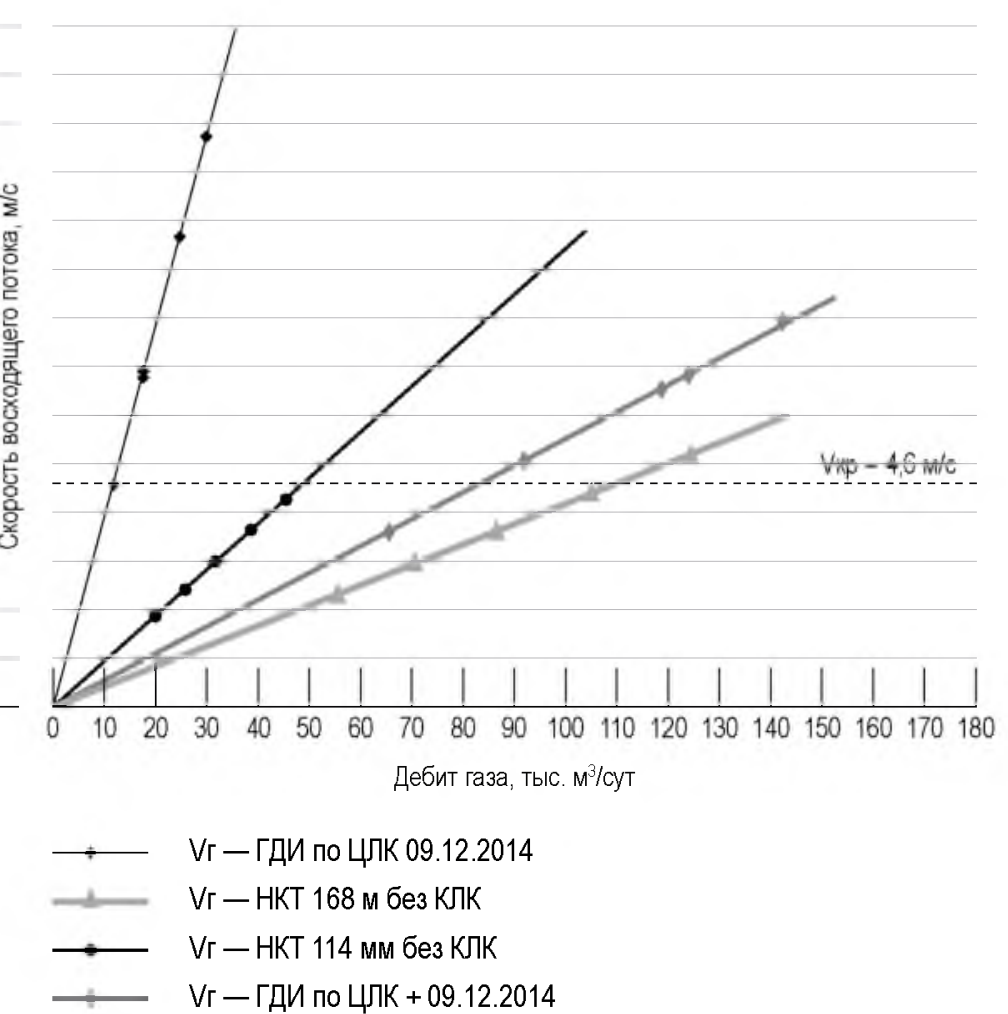

Puc. 1.

\section{Скорости восходящего потока газа на режимах ГДИ скважины №514.}

Fig. 1. The speed of the upward flow of gas on the modes GDI well number 514.

лам, образованным двумя концентрически размещенными одна в другой колоннами труб - центральной лифтовой колонне (ЦЛК) и основной лифтовой колонне - межколонному пространству (МКП). Внизу обе колонны сообщаются между собой. На устье скважины потоки газа соединяются и поступают в газосборный коллектор (ГСК). Технология КЛК используется для создания условий, при которых вода, поступающая на забой скважины, выносится из скважины потоком газа.

Для управления процессом эксплуатации скважины установлен технологический комплекс контроля (ТК КЛК) производства ООО НПФ «ВЫмпел». Общий вид скважины № 514 с комплексом управления ТК КЛК приведен на рисунке 2.

ТК КЛК реализует задачу оптимизации режима эксплуатации обводняющихся скважин посредством автоматического поддержания в ЦЛК дебита газа, незначительно превышающего (на 10-20\%) минимальный дебит га- 


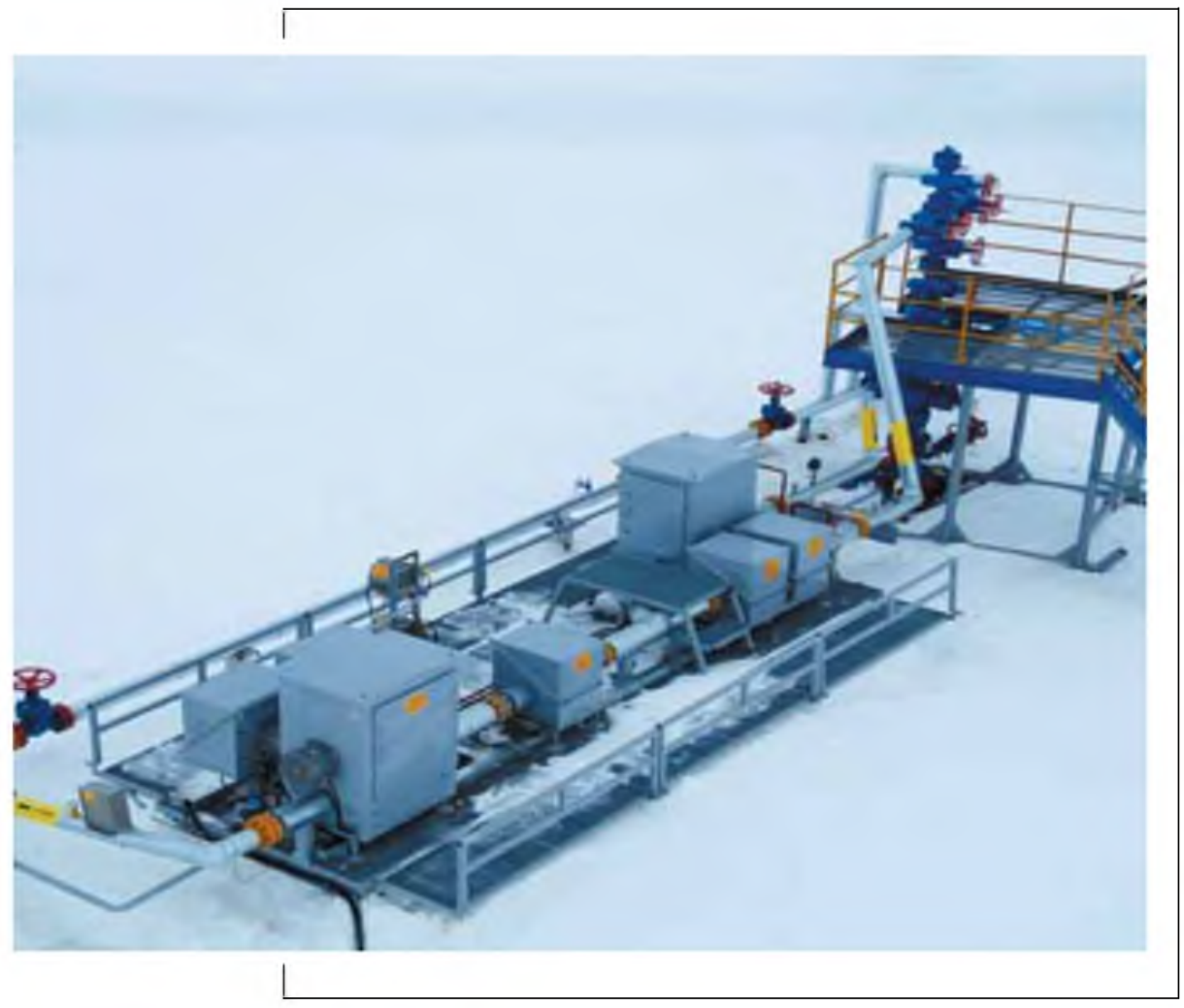

Pиc. 2.

Скважина № 514 Уренгойского НГКМ, оборудованная КЛК. Fig. 2. Well No. 514 of Urengoi OGKM, equipped with KLK.

за, необходимый для удаления жидкости по мере её поступления в скважину. Базовый дебит рассчитывается для колонн разного размера, давлений и температур потока газа. Расчет производится по методике ООО «Газпром ВНИИГАЗ» с использованием программного обеспечения ООО «НПФ «Вымпел». Поддержание заданного значения дебита осуществляется путем непрерывного контроля расхода газа из ЦЛК и изменением величины расхода газа из МКП путем автоматического регулирования на регулирующем устройстве дебита (РУД) МКП.

Для обеспечения безгидратного режима эксплуатации на линии ЦЛК и МКП предусмотрена подача ингибитора гидратообразования (метанола). Схема площадки управления скважины № 514, оборудованной КЛК, приведена на рисунке 3 . В состав комплекса управления КЛК входят двухфазный расходомер ДФР-01, расходомер газа «ГиперФлоу», регулирующее устройство дебита газовой скважины РУД-02, система подачи ингибитора СПИ-02. 


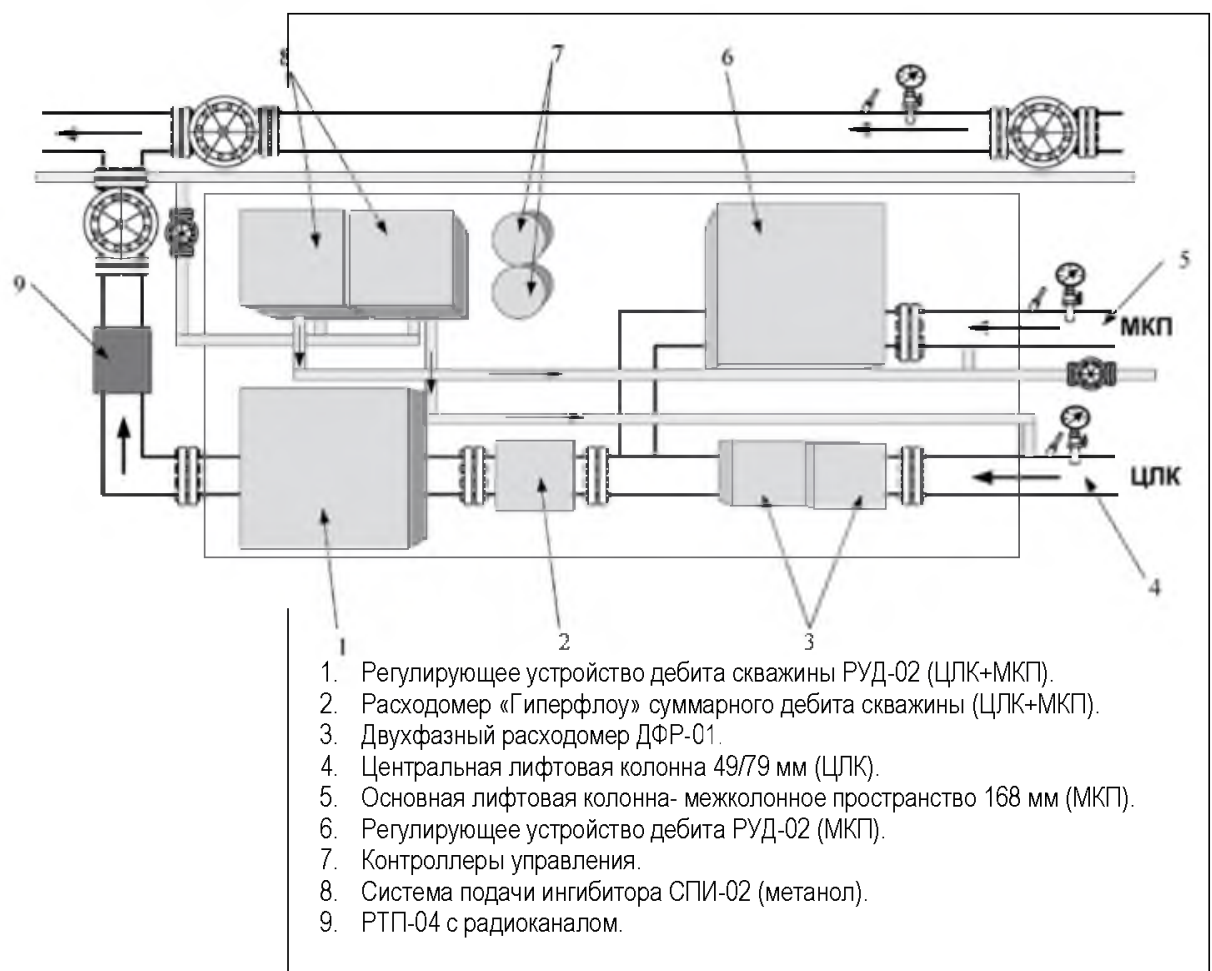

Рис. 3.

Площадка управления скважинного оборудования скважины № 514.

Fig. 3. Well control station platform of well number 514 .

\section{Результаты исследований и их обсуждение}

Первоначально расчет параметров эксплуатации скважины № 514 выполнен в 2013 году с помощью программного обеспечения ООО «НПФ «Вымпел». В основу работы управляющего комплекса положено поддержание дебита газа по центральной лифтовой колонне $750 \mathrm{~m}^{3} /$ час (18 тыс. $\mathrm{M}^{3} /$ сутки).

16 декабря 2013 г. скважина № 514 введена в работу и по настоящее время устойчиво эксплуатируется на УКПГ-5. За все время не было отмечено ни одного случая остановки скважины по причине накопления жидкости на забое и снижения дебита газа. Вынос воды происходит автоматически через центральную лифтовую колонну под контролем технологического комплекса контроля и управления режимами работы газовых скважин. На 01.10.2019 г. накопленная добыча газа из скважины № 514 после оборудования КЛК по данным эксплуатационных рапортов составила 89,8 млн м ${ }^{3}$ 


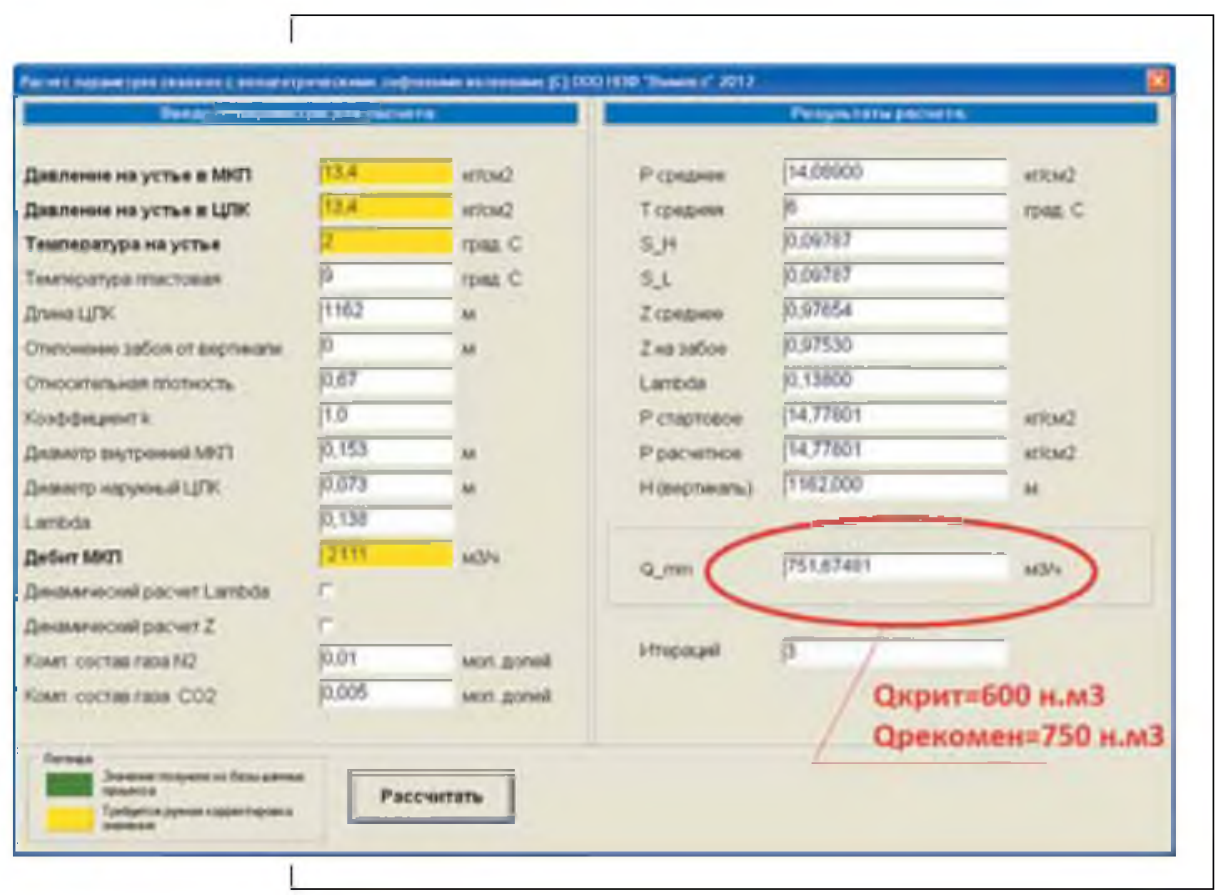

Рис. 4. Расчет дебита газа по ЦЛК скважины № 514 по методике ВНИИГАЗ с использованием ПО ООО НПФ «Вымпел».

Fig. 4. Calculation of gas flow rate in the CLK of well No. 514 according to the VNIIGAZ methodology with the use of software LLC NPF «Vympel».

Для мониторинга режима эксплуатации в реальном времени обеспечена передача динамики значений расходньх и термобарических параметров на АРМ УКПГ и в информационно-управляющую систему дистанционного управления (ИУС ДУ) ООО «Газпром добыча Уренгой». В таблице 1 представлены средние параметры работы скважины № 514 за 2014-2019 гг. Динамика дебитов газа по каналам ЦЛК и МКП, а также устьевого давления скважины по показаниям ИУС ДУ приведена на графике рис. 5.

При разработке залежей на истощение пластовой энергии забойные давления в скважинах постепенно снижаются, что приводит к снижению плотности газового потока и в соответствии с формулой (1) к увеличению значения минимально-необходимой скорости газа для полного и непрерывного выноса жидкости с забоя скважины.

В начале 2018 года минимально-необходимая скорость газа для полного и непрерывного выноса жидкости с забоя скважины № 514 составляет 

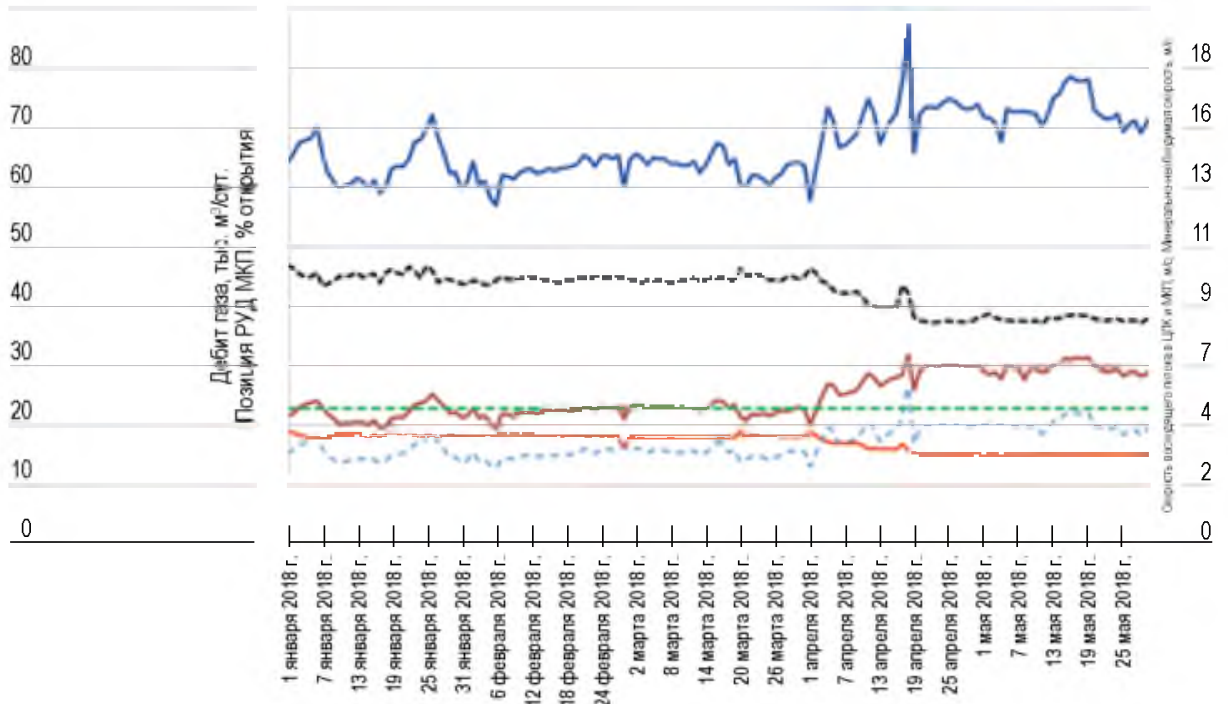

Дебит газа по ЦПК, тыс. $\mathbf{M}^{3 / c y}$

Сумарный дебит газа по ЦПК + МКП, тыс. $\mathrm{m}^{3} / \mathrm{cy}$ Минимально необходимая скорость газа, м/c

Позиция РУД, \% открытия Скорость газа в МKП, $M / c$ Скорость газа в ЩЛК, $\mathrm{m} / \mathrm{c}$

Рис. 6.

Параметры скв. №514 до и после изменения значения «уставки» минимально-необходимого дебита газа по ЦЛК.

Fig. 6. Parameters well No. 514 before and after changing the value of the "setpoint" for the minimum required gas flow rate in the CLK.

уже 5,1 м/с, что на $86 \%$ ниже значения фактической скорости газа в ЦЛК. С целью оптимизации технологического режима работы скважины №514 в марте 2018 года выполнен расчет оптимальных параметров эксплуатации скважины. Минимально-необходимый дебит (МНД) газа по ЦЛК составил $630 \mathrm{~m}^{3} /$ час $(15,1$ тыс. м³/сут). С 3 апреля 2018 г. «уставка» дебита газа по ЦЛК была поэтапно снижена с $750 \mathrm{~m}^{3} /$ час до $630 \mathrm{~m}^{3} /$ час. Параметры скважины до и после изменения «уставки» МНД газа по ЦЛК представлены на графике (рис. 6).

\section{Выводы}

В результате проведенной корректировки при практически одинаковых устьевых давлениях произошло увеличение суммарного среднего дебита газа на 19\% - с 62 до 74 тыс. м³/сут. Таким образом, мониторинг параметров эксплуатации скважины и своевременная корректировка параметров работы комплекса управления ТК КЛК позволили оптимизировать технологический режим скважины. Данная оптимизация будет применяться и в дальнейшем по мере снижения пластового давления в сеноманской залежи. 
В заключении следует отметить, что внедрение технологии концентрического лифта обеспечило стабильную работу скважины № 514 без технологических продувок. Комплекс контроля и управления работой скважины ТК КЛК обеспечил надежную эксплуатацию малодебитной газовой скважины сеноманской залежи УНГКМ в условиях обводнения конденсационными водами. Реконструкция газовых скважин без глушения и их дальнейшая эксплуатация по концентрическим лифтовым колоннам обеспечит эффективную добычу газа из сеноманской залежи на поздней и завершающей стадиях разработки.

\section{Библиографический список}

1. Авторский надзор за реализацией проектных решений технологического проекта разработки сеноманской залежи месторождений Большого Уренгоя (Уренгойское и Северо-Уренгойское НГКМ) в 2017 году. М: Газпром ВНИИГАЗ, 2017.

2. Ли Г.С., Стасенкова Е.В., Катаева М.А. Результаты лабораторных экспериментов по оценке устойчивости пород-коллекторов сеноманской залежи к разрушению конденсационными и пластовыми водами. Сборник научных трудов ООО «ТюменНИИгипрогаз». Тюмень: Флат, 2011. С. 69-73.

3. Дикамов Д.В., Мазанов С.В. Минликаев В.З., и др. Перспективное направление использования двухрядных лифртов, управляемых современными средствами автоматизации, для удаления жидкости из скважин Ямбургского месторождения // Материалы НТС ОАО «Газпром» «Современное состояние и пути совершенствования и технологий промысловой подготовки углеводородного сырья на месторождения ОАО "Газпром"», секция: «Добыча и промысловая подготовка газа» (Тюмень. 2-6 июня 2008). М.: ИРЦ Газпром, 2008. С. 12-17.

4. Дикамов Д.В., Корякин А.Ю., Минликаев В.З. и др. Новый этап совершенствования технологий эксплуатации скважин сеноманских залежей // Газовая промышленность. М.: Газоил пресс, 2014. № 3. С. $85-88$.

5. СТО Газпром 2-2.3-1017-2015 «Эксплуатация газовых скважин месторождений Надым-Пур-Тазовского региона по концентрическим лифтовым колоннам».

6. Мандрик Е.В., Мельников С.А., Плосков А.А., Моисеев В.В., Харитонов А.Н., Памужак С.Г. Эксплуатация газовых скважин в условиях активного водо- и пескопроявления // научно-технический сборник Вести газовой науки. М.: Газпром ВНИИГАЗ, 2018. №1(33). С. 235-242. 


\section{References}

1. Author's supervision over the implementation of design solutions of the technological project of development of the Cenomanian Deposit of the Bolshoy Urengoy (Urengoy and North Urengoy $\mathrm{ngcm}$ ) fields in 2017. Moscow: Gazprom VNIIGAZ, 2017.

2. Li G.S., Stasenkova E.V., Kataeva M.A. results of laboratory experiments to assess the stability of reservoir rocks of the Cenomanian Deposit to destruction by condensation and formation waters. Collection of scientific works of LLC TyumenNIIgiprogaz. Tyumen: LLC "flat", 2011, C. 69-73.

3. Dikamov D.V., Mazanov S.V. minlikaev V.Z., et al. Perspective direction of use of double row elevators controlled by modern automation means for removal of liquid from wells of Yamburgsky field /I Materials of NTS of JSC Gazprom "Modern state and ways of improvement and technologies of field preparation of hydrocarbon raw materials on fields of JSC Gazprom", section: "Production and field preparation of gas". (Tyumen. 2-6 June 2008). Moscow: IRTS Gazprom, 2008. Pp. 12-17.

4. Dikamov D. V., Koryakin A. Yu., minlikaev V.Z. et al. New stage of improvement of technologies of operation of wells of Cenomanian deposits // Gas industry. Moscow: Gazoil press, 2014. No. 3. Pp. 85-88.

5. OS Gazprom 2-2. 3-1017-2015 "Operation of gas wells of fields of Nadym-PUR-Taz region on concentric lift columns".

6. D.V. Izyumchenko, Ye.V. Mandrik, S.A. Melnikov, A.A. Ploskov, V.V. Moiseyev, A.N. Kharitonov, S.G. Pamuzhak Operation of gas wells in conditions of active water and sand manifestation. M.: Gazprom VNIIGAZ, 2018. №1(33). C. 235-242.

Поступило в редакцию 18.11.2019, принята к публикации 02.12.2019

\section{O6 авторах}

Пономарев Александр Иосифович доктор технических наук, профессор, ФГБОУ ВО «Уфимский государственный нефтяной технический университет», заведующий кафредрой «Разработка и эксплуатация газовых и нефтегазоконденсатных месторождений» $+7(917) 342-28-30$, e-mail: pnmrv@mail.ru 
Рагимов Теймур Тельманович заместитель начальника цеха ГКП-5 УГПУ ООО «Газпром добыча Уренгой».

$+7(922) 095-44-95$,

e-mail: teymur.ragimov@mail.ru

Шигидин Олег Александрович начальник отдела исследований скважин ИТЦ ООО «Газпром добыча Уренгой» $+7(902) 621-28-19$,

e-mail: teymur.ragimov@mail.ru

\section{About the authors}

Ponomarev Alexander losifovich doctor of technical Sciences, Professor, Ufa state oil technical University, head of the Department "Development and operation of gas and oil and gas condensate fields" $+7(917) 342-28-30$

e-mail: pnmrv@mail.ru

Ragimov Teymur Telmanovich Deputy head of shop GKP-5 UGPU LLC "Gazprom dobycha Urengoy".

$+7(922) 095-44-95$,

e-mail: teymur.ragimov@mail.ru

Shigidin Oleg Alexandrovich head of well research Department, ITC LLC "Gazprom dobycha Urengoy".

+7 (902)621-28-19,

e-mail: teymur.ragimov@mail.ru 